\title{
Islamic Health Promotion Based on Health Communication in Indonesia of Qur'anic Perspective
}

\author{
Abdul Hafiz ${ }^{1}$, Arif Sumantri ${ }^{2}$, Didin Saepudin ${ }^{3}$ \\ \{abdul.hafiz18@uinjkt.ac.id ${ }^{1}$, arif.sumantri@uinjkt.ac.id ${ }^{2}$, didin.saepudin@uinjkt.ac.id ${ }^{3}$ \} \\ Sy arif Hiday atullah State Islamic University of Jakarta, Indonesia ${ }^{123}$
}

\begin{abstract}
Indonesia with its majority Muslim populace has gigantic potential in adding to changes in wellbeing conduct. Islam is a religion that emphatically urges people to live spotless, solid, and naturally benevolent. There are numerous stanzas in the Qur'an and Hadith that contain messages about tidiness and wellbeing. Wellbeing with its worldview clarifies the significance of Islamic lessons and the other way around so that there is no hole between the loftiness of Islamic lessons with wellbeing practices in regular day to day existence. The Ottawa Charter, which structures the premise of the wellbeing advancement methodology, has been demonstrated to have joined with Islamic ideas that lead to three essential ideas in Islam, in particular the Pillars of Faith, Pillars of Islam, and Islamic Law and the arrangement of an Islamic wellbeing hypothesis. This examination intends to clarify the mix of the idea of Islam with the fundamental idea of well-being advancement as an elective way to deal with well-being conduct change.
\end{abstract}

Keywords: Islamic Health, Health Promotion, Health Communication.

\section{Introduction}

Islam is a religion that strongly encourages people to live clean, healthy, and environmentally friendly. Quite a lot of verses of the Qur'an and the Hadith of the Prophet contain various messages related to these suggestions.

Starting from the suggestion to cleanse the body, the term cleanliness in the Qur'an is listed with Thaharah (purity or cleanliness), the word is mentioned in the Qur'an 31 times. Among them: "And clean your clothes". (Al-Mudatstsir (74); 4).

Then purify, eat halal and good food up to the prohibition of damaging nature and the environment. Health communication with its healthy paradigm can be used in providing various information related to the application of Islamic values or vice versa so that there is no gap between the glory of Islamic teachings and the behavior of daily life from the point of health.

And among them, some pray, "O our Lord, grant us goodness in the world and goodness in the afterlife, and protect us from the punishment of hell" (Al-Baqarah (2); 201). One element of the goodness of the world is health. Therefore, we must try to maintain existing health, and restore it when it disappears. 


\section{Health Promotion}

The WHO Health Promotion Conference globally has shaped the concepts, principles, and areas of action that place health promotion in the broader context of globalization. (Ottawa 1986 and Bangkok 2005).

The concept of health promotion is a development of the concept of health education, taking place in line with changes in the paradigm of public health. The conference has examined public policy-making (Adelaide 1988) and the creation of a supportive environment (Sundsvall 1991). They have been seen as playing an important role in capacity building for health promotion and in overcoming health determinants (Jakarta 1997 and Mexico 2000).

They have called for action to close the implementation gap between evidence and concrete applications in health development (Nairobi 2009). The 8th Global Conference on Health Promotion (Helsinki 2013) reviews experiences in engaging in Health in All Policy approaches and establishes guidance for concrete actions in countries at all levels of development (WHO, 2016).

In 1986 in Ottawa, Canada, an international health promotion conference took place which resulted in the Ottawa Charter (Ottawa Charter). The first International Conference on Health Promotion, meeting in Ottawa 21st day this November 1986, hereby presents this CHARTER for actions to achieve Health for All in 2000 and beyond (WHO, 2016).

\subsection{International Health Promotion Policy}

The basis of international health promotion policies has been formed since the first conference in ottawa Canada city was held in 1986 with the theme "towards new public health" and produced the basis for health promotion, the Ottawa Charter. Furthermore, the health promotion conference continued to take place in a different place until the last, namely the seventh conference in Kenya in 2009. Each conference will produce a new strategy to solve problems that arise in that period in the world. (E De Leeuw and A Hussein, "Islamic Health Promotion and Interculturalization,", 1999)

The health promotion conference I was held in the city of Ottawa Canada in 1986 with the theme "Towards a new public health" resulting in the Ottawa charter. The Ottawa Charter mentions nine prerequisite factors for health: peace, shelter, education, food, income, balanced ecosystems, sustainable resources, prosperous social conditions, and equity. The Ottawa Charter has the objectives of health promotion namely: Advocacy (convincing policymakers the proposed rules are important), bridging (between the health and other fields), and enabling (making the community independent). There are five health promotion strategies in the Ottawa Charter, namely developing public policies relating to health, creating a healthy environment, building an active community, developing community skills, and reorienting the health care system. (Naidoo, J, and J Wills. Bailliere Tindal: Harcourt Publishers Limited, 2000).

The second health promotion conference in Adelaide, Australia in 1988 with the theme "Building health-oriented public policies". In the second conference, the strategies used led to support the creation of people who live in a healthy environment and behave healthily. To achieve this goal, six strategies are used, namely, public health policy, seeking to revitalize health human rights values, equitable access to health services, accountability for health programs, improving services, and partnerships. The conference also shared public policy priorities in the health sector, namely women's programs, food and nutrition, tobacco and alcohol, and a good environment. 
The third health promotion conference in Sundvall, Sweden in 1991 with the theme "Creating an environment that supports health". This conference produces a model that is run practically in health promotion, namely the Health promotion strategy analysis model (HELPSAME) in the form of an analysis of experiences in creating a supportive environment, Sundsvall pyramid of a supportive environment, and Supportive environmental action model in the form of facilitators in groups. (E De Leeuw and A Hussein, "Is lamic Health Promotion and Interculturalization,", 1999)

The fourth health promotion conference in Jakarta, Indonesia with the theme "New actor in a new era" in 1997. This conference produced the Jakarta Declaration which contained a new approach to health promotion. The Jakarta Declaration consists of four approaches, namely a comprehensive approach in the form of health promotion carried out simultaneously, an approach through the arrangement of health experts taking part in government chairs, educational institutions, and health service institutions, community participation approaches, and health learning approaches. (E De Leeuw and A Hussein, "Is lamic Health Promotion and Interculturalization,", 1999)

The fourth health promotion conference produced a priority on improving health. Pertam enhances social responsibility in health carried out by health service providers. The second priority is increasing investment in health development. The third priority is to increase partnerships to improve health services. The fourth priority is to increase the ability of the community in community empowerment and develop infrastructure gradually and continue to increase the intensity of health promotion. (Naidoo, J, and J Wills. Bailliere Tindal: Harcourt Publishers Limited, 2000).

The fifth health promotion conference in Mexico, Mexico in 2000 with the theme "bridging the equality gap". The conference produced ministry programs in the form of eight types, namely respecting the achievement of health standards as a positive asset for life comfort and growth in socio-economic development and equity, understanding health promotion as a shared responsibility, improving health services, realizing many problems have not been resolved, infections reduce the success of the health sector, the importance of collaboration, the promotion of health of basic public components, and effective strategies. (Naidoo, J, and J Wills. Bailliere Tindal: Harcourt Publishers Limited, 2000).

\subsection{Health Communication}

Health communication is "the focal social procedure in the arrangement of human services conveyance and the advancement of public health" (Kreps, 1988, p. 238).

The most significant asset for advancing health is important health data that can guide individuals' health choices and can rouse them to receive sound practices. Also, important health data must be gotten to through the procedure of correspondence. Access to relevant, auspicious, precise, and enticing health information can empower individuals' dynamic support at home, in the social insurance framework, and in-network settings.

Over 50 years of health communication research gives solid proof that vital wellbeing correspondence endeavors can help lessen wellbeing dangers, ailment incidence, grimness, and mortality, just as improve personal satisfaction for in danger populations by empowering in danger people to settle on educated choices about maintaining a strategic distance from health dangers, recognizing medical is sues at a beginning period when they are most treatable, and getting the best care to address medical problems (Kreps, 2003, 2012a, 2012b; Kreps and Sivaram, 2008; Kreps and Sparks, 2008; Neuhauser and Kreps, 2003, 2010). 
In any case, look into additionally demonstrates that numerous endeavors to convey wellbeing neglect to meet their objectives, or have just unobtrusive impacts (National Research Council, 2000). A key shortcoming is that customary wellbeing correspondence is regularly excessively conventional and not adequately lined up with the capacities, inclinations, and life circumstances of explicit crowds (Emmons, 2000; Neuhauser and Kreps, 2010).

Assessment research ought to be incorporated with all periods of well-being advancement endeavors (Kreps, 2013). Albeit customary assessment plans for well-being projects have would in general stress standard and result organizes, the developing pattern is to have substantially more accentuation on developmental assessment and iterative changes to the correspondence intercession (Neuhauser, Kreps, and Syme, 2013).

This rising model draws from hypothesis and strategies for the structure sciences, clien $\mathrm{t}-$ focused and participatory plan and activity look into (Minkler and Wallerstein, 2008; Neuhauser, Kreps, and Syme, 2013). In those sorts of assessments, the way toward structure and step by step testing of the communication intercession is similarly as significant as deciding the impacts.

Another exercise gained from communication research is that well-being data is progressively compelling when displayed through numerous strengthening messages conveyed through various reciprocal corres pondence channels at a few points after some time. This numerous reciprocal message system is educated by the correspondence standards of excess and fortification to improve message presentation and effect (Donohew, Lorch, and Palmgreen, 1998).

These standards recognize the significance of rehashing wellbeing messages because long haul presentation is frequently vital for individuals to see new ideas, particularly for in danger populaces. Media methodologies help suit individuals' changing inclinations for accepting data, and help keep individuals' consideration by exhibiting data in various, "crisp" ways. Also, explore is progressively exhibiting the intensity of utilizing account (narrating) and striking symbolism in outlines and photographs to teach and persuade spectators who have restricted wellbeing education. These methodologies are additionally valuable for crowds who have issues with numeracy (seeing numerically exhibited data, for example, measurements and numerical hazard gauges) (Maibach \& Parrott, 1995).

\subsection{Salutogenesis Factor}

This term was introduced by Aaron Antonovsky in 1979 through a book called "Health, Stress \& Coping". Salutogenesis is the opposite of pathogenesis. If the term I mentioned last attempts to "cure" pathological causes, Salutogenesis seeks to preserve \& strengthen sources of life force (such as health \& well-being).

According to Aaron Antonovsky (in The Handbook of Salutogenesis, 2017), the sense of coherence is an important aspect that can support the above efforts. The book also mentions Aaron Antonovsky's (1979) definition of self-coherence, that is :

"a global orientation that expresses the extent to which one has a pervasive, enduring though dynamic feeling of confidence that one's internal and external environments are predictable and that there is a high probability that things will work out as well as can reasonably be expected".

The intended definition of the above definition relates to a person's ability to attach themselves to a variety of resources that can help him deal with sources of stress (Mittelmark $\&$ Bauer, 2017). According to them, the higher the sense of coherence a person has, the more 
he can use coping stress resources. Also, the greater the level of success in managing the pressures in life.

Aaron Antonovsky knew the importance of a sense of coherence to health and well-being after he changed his perspective from "what causes people to get sick?" To "what makes a person stay healthy?". This sense of coherence became a key concept in the Salutogenesis Model that he designed, and is still growing today. (Naidoo, J, and J Wills. Bailliere Tindal: Harcourt Publishers Limited, 2000).

I think that the term Salutogenesis introduced by Aaron Antonovsky has the same basic principles as the Positive Psychology approach. The difference is that salutogenesis is closely related to physical health because the focus is on the recognition of the ease-disease inherent in a person; whereas Positive Psychology is closely related to mental health, through the concept of well-being. In other words, both are applied to different fields of science \& intervention-practical approaches; one is medical, the other is psychology. (Naidoo, $\mathrm{J}$, and $\mathrm{J}$ Wills. Bailliere Tindal: Harcourt Publishers Limited, 2000).

\subsection{Sense of Coherence}

Several studies have shown a definite relationship between religious values and health is sues. At least 28 of the same studies have been analyzed and found a consistent, albeit small, relationship with controlled variables.

Levin and Vanderpool, "Is Frequent Religious Attendance Conducive to Better Health?"

As has been previously known this relationship is not an accurate indication of physical health, but various other studies have shown well the positive effects of religion on health that are measured objectively. Several studies on the relationship between religion and morbidity have been carried out, and its effects have been found in most diseases, including CHD, stroke, several types of cancer, colitis, and enteritis, and show the possibility of a definite relationship between religion and health.

Levin, "How Religion Influences Morbidity and Health,", p. 860.

The term "sense of coherence" is used to imply a person's ability to adapt to their environment and to be healthy amid a variety of suppressor factors. (Antonovsky, "Health, Coping and Stress 1st ed," p. 41)

Through empirical evidence again "Sense of coherence" is seen as a comprehensive orientation that shows the level of pervasiveness that a person has, through a dynamic selfconfidence of (1) stimulus originating from one's internal and external environment in his life is something that is structured, can be predictable and explainable; (2) A person has the resources to fulfill the demand indicated by the stimulus; and (3) These requests are challenges, worthy of investment and included ". In-depth reviews of the various literature indicate that there are not many writings that discuss the relationship between health behavior and Islam. Islamic ideas regarding its relationship with public health promotion, including covering:

1. Zat al Bain: core bonds in society.

2. Fard - El Kifaya (fardhu kifayah): A shared obligation to care for and treat others. (Nicola Ruck, "Child Health and Islam," p. 37.)

De Leeuw and Hussein paid attention to the 5 strategic areas of the Ottawa Charter and showed its relationship to concepts in Islam such as Da'wah, Sharia, Shuura, Hisba, and Waqaf. (E De Leeuw and A Hussein, "Islamic Health Promotion and Interculturalization," p. $350)$. 


\subsection{Determining Factor}

There is a shared understanding that hereditary qualities, condition, and way of life shape the fundamental factors that determine an individual's health status. (Kemm and Close, Health Promotion: Theory and Practice, p. 79)

Health promotion strategies try as much as possible to influence these determinants to improve wellbeing status. Since these determinants are a piece of different fields of science, the idea of well-being advancement can be said to have united a few examinations in the field of science in one umbrella. (Naidoo and Wills, Health Promotion Foundations for Practice, p. 83.)

In 1986 the WHO first health promotion conference was held, declaring one of the most comprehensive definitions of health promotion, the process of community empowerment to improve control of health and improve its health status. (Bunton and MacDonald, Health Promotion: Disciplines and Diversity, p. 112)

Since then there have been many writings and studies on health promotion and various ways to design, plan, and implement health promotion strategies. There are many ways to start or implement a health promotion program. Broadly speaking, the method considered the most successful is a method that is based on a theoretical framework. There is sufficient evidence in the implementation of health promotion that suggests the use of a theoretical framework to increase the chances of success in achieving the initial goals of a health promotion program. (Kemm and Close, Health Promotion: Theory and Practice, p. 79)

Most health promotion strategies use more than one theory in developing an intervention plan. So far the discussion has shown the link between religion and health, illustrating various Islamic concepts derived from the three main concepts of Islam that lead to health. (Nutbeam and Harris, Theory in a Nutshell: A Practitioner's Guide to Commonly Used Theories and Models in Health Promotion, p. 68).

However, what is still missing is a detailed description of how the real application of Islamic concepts can be useful and used in the implementation of the theory of health promotion models. As an illustration of how Islamic concepts and ideas can be integrated into current health promotion concepts and ideas. (Green and Kreuter, Health Promotion Planning: An Educational and Ecological Approach, p. 149)

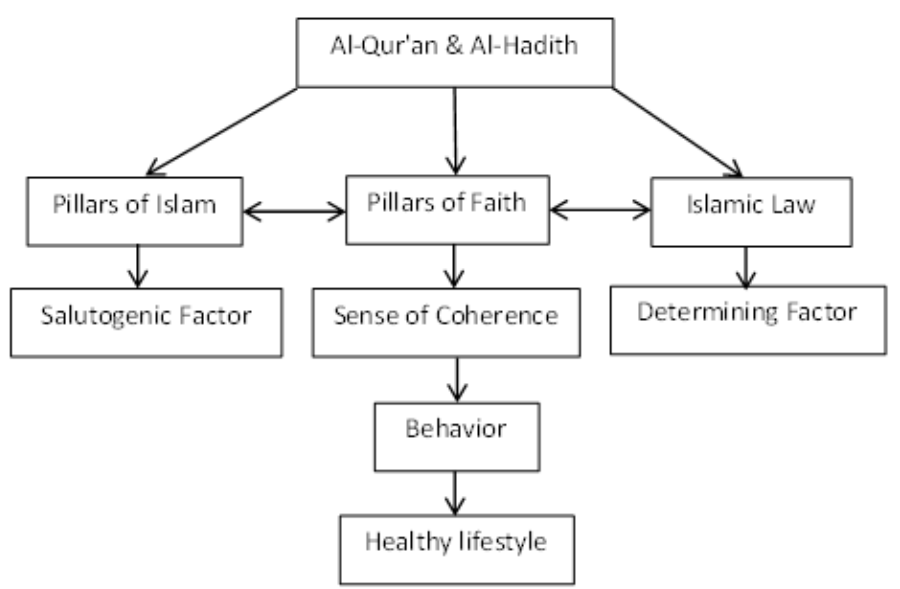

Fig. 1. Islamic Health Theory. 


\subsection{Health Communication in the Qur'an}

Putting the Islamic Concept into the Implementation of Health Communication as in the following verse:

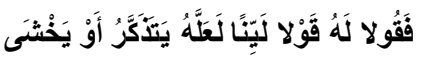

"So the two of you spoke to him with Qulan Layina - gentle words ..." (Surah Thaha: 44).

قوَّلا لَيًَّا the heart. In the interpretation of Ibn Kathir mentioned, what is meant by layina is the word satire, not by the words frank or straightforward, especially rude.

The above verse is the command of Allah SWT to the Prophet Moses and Aaron to speak softly, not rudely, to Pharaoh. With قَّوْلا كَيَنًا , the communicant's heart (the person invited to communicate) will feel touched and his soul moved to receive our communication message. (E De Leeuw and A Hussein, "Is lamic Health Promotion and Interculturalization,", 1999)

According to Tafsir Al-Qurtubi, this verse recommends warning and sympathetically prohibiting something evil through good expressions or words and it should be done using gentle words, especially if it is done against the authorities or people of rank.

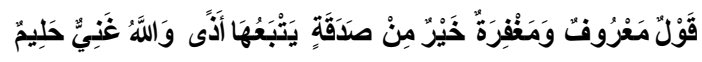

"Good words - and forgiveness is better than alms accompanied by something painful (the recipient's feelings). Allah is the most wealthy and the most helpful. "(Surat al-Baqarah: 263).

The principle of Is lamic communication قَوْلُ مَعْرُوفتُ means good words, proper expressions, polite, using innuendo (not rude), and not painful or offensive.

also means talks that are useful and cause good (maslahat). In the Tafsir Al-

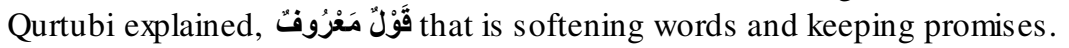

\subsubsection{Healthy Lifestyle According to the Qur'an}

Al-Qur'an teaches humans to always try to get good in terms of the world, or the hereafter. This is evidenced by the word of God which says:

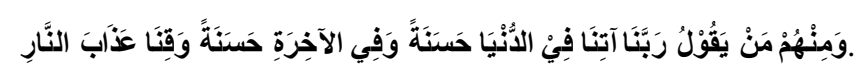

And among them, some pray, "O our Lord, grant us goodness in the world and goodness in the afterlife, and protect us from the punishment of hell" (Surat al-Baqarah (2); 201).

One element of the goodness of the world is health. Therefore, we must try to maintain existing health, and restore it when health is lost. (Maulana, A.O. University of Maastricht, 2002)

Islam is very concerned about health issues. This is evidenced by the many verses of the Qur'an and the hadith that command humans to live healthy, including:

\subsubsection{Personal Hygiene}

The term cleanliness in the Qur'an is listed with Thaharah (purity or cleanliness), the word is mentioned in the Qur'an 31 times. Among them:

$$
\text { وَثِيَبَابَكَ فَطَهِّر }
$$


"And clean your clothes". (Surah Al-Mudatstsir / 74; 4).

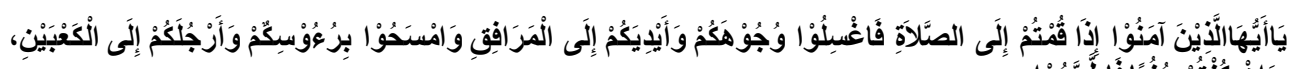

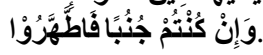

"O believers. If you want to pray, then wash your face and hands to the elbows, and sweep your head, and (wash) your feet to the ankles. If you junub then clean it (by bathing)" (Surah Al-Ma'idah / 5: 6).

The above proposition tells humans to keep cleaning themselves, this is by the concept of health which strongly encourages humans to live cleanly. Because of the cleanliness of the base of health. (Maulana, A.O. University of Maastricht, 2002)

\subsubsection{Healthy Eating Patterns}

One of the ways taught by Islam to achieve health is to set a good diet. The teachings of Is lam in managing food there are several things, including:

- Eat halal and good food

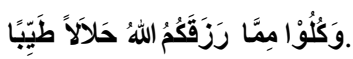
$8)$.

"And eat from what God has given you as a halal and good fortune". (Surat al-Ma'idah/5:

- Not excessive in eating and drinking.

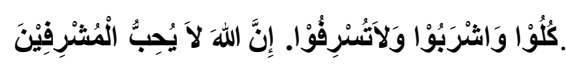

"Eat and drink, but don't overdo it. Surely Allah does not like people who are overdone". (QS. Al-A`raf; 31).

- Eat nutritious foods

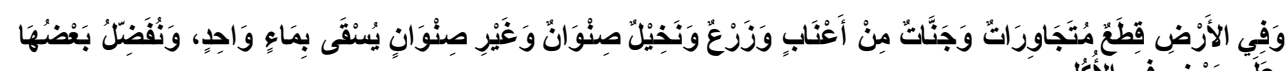

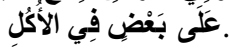

"And on earth, there are adjoining parts, vineyards, plants, branched and unbranched date palms, doused with the same water, but We are exaggerating one plant from another in taste." (Qs. Ar-Ra`d / 13; 4).

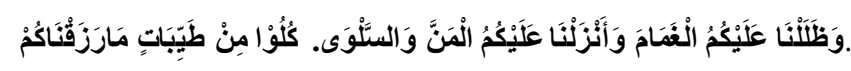

"And We shade you with clouds, and We send down to you mann and salwa. Eat (food) that is good from the sustenance that we have given you". (Al-Baqarah / 2; 57).

- Do not eat that is forbidden.



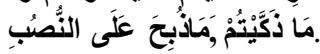


"Forbidden to you (eat) carcasses, blood, pork, and (meat) animals slaughtered not in the name of Allah, strangled, beaten, fallen, gored, and pounced on wild animals, except for those of you butchered ". (Surat al-Ma'idah / 5; 3).

- Do not consume intoxicating drinks

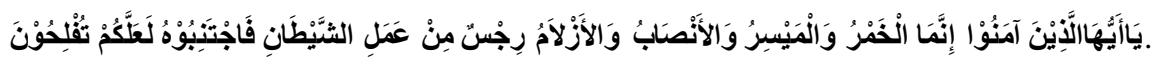

"O believers. Indeed alcoholism, gambling, (sacrificing) for idols, and drawing lots of fortune with arrows, are abominable and include the actions of the devil. So stay away (actions) that you are lucky ". (Surat al-Ma'idah / 5; 90).

\subsection{Health Belief Model (HBM)}

The Health Belief Model (HBM), a cognitive model, is used to predict health improvement behaviors that are used to explain the failure of broad community participation in disease prevention or detection programs. According to HBM, the possibility of someone taking precautions is influenced by beliefs and health assessments (Maulana, 2009) which are influenced by:

\subsubsection{Threats felt from illness or injury (perceived threat of injury or illness)}

This relates to the extent to which a person thinks that illness or pain is a threat to himself. Therefore, if the perceived threat increases, prevention behavior will also increase. (Maulana, H. D., 2009)

\subsubsection{Benefits and disadvantages}

Benefits and disadvantages. Consider the advantages and disadvantages of behavior to decide whether to take preventative action. (Maulana, H. D., 2009)

\subsubsection{Benefits and disadvantages}

Hint behaves. The hint of behavior is called belief in a prominent position. This can take the form of outside information or advice on health issues (eg mass media, campaigns, advice from others, illness from other family members or friends). (Maulana, H. D., 2009)

HBM has a function as prevention or preventive model (Stanley \& Maddux; 1986 in Community Health Nursing, 2010). 6 components of this HBM, that is :

1. Perceived Susceptibility.

2. Perceived Severity.

3. Perceived Benefits.

4. Perceived Barriers.

5. Cues to Action.

6. Self Efficacy.

(James E. Maddux and Melinda A. Stanley, 1986) 
Figures. Concept

1. Perceived Susceptibility: For example, someone believes that everyone has the potential to get cancer.

2. Perceived Severity: For example, individuals believe that smoking can cause cancer.

3. Perceived Benefits: For example doing healthy behaviors such as routine medical check-ups. If you don't smoke, he won't get cancer.

4. Perceived Barriers: For example, if you don't smoke it doesn't taste good, your mouth feels sour.

5. Cues to Action: The doctor's advice or recommendations become cues to action to act in the context of quitting smoking.

6. Self Efficacy: Feel confident with healthy behavior. (James E. Maddux and Melinda A. Stanley, 1986)



Fig. 2. Health Belief Model (HBM).

\section{Conclusions}

Health issues are still a topic that will never be discussed, as changes in health behavior in society is also still a challenge for all parties. Indonesia with its majority Muslim population has tremendous potential in contributing to changes in health behavior. Is lam is a religion that strongly encourages humans to live clean, healthy, and environmentally friendly. There are many verses in the Qur'an and Hadith that contain messages about cleanliness and health. Health with its paradigm explains the meaning of Islamic teachings and vice versa so that there is no gap between the majesty of Islamic teachings with health behaviors in everyday life. The Ottawa Charter, which forms the basis of the health promotion strategy, has been indicated to have links with Is lamic concepts that lead to three basic concepts in Islam, namely the Pillars of Faith, Pillars of Is lam, and Islamic Law and the formation of an Islamic health theory. This study aims to explain the integration of the concept of Islam with the basic concept of health promotion as an alternative approach to health behavior change in society.

Acknowledgements. There is no reply that the author can give other than prayer and thanks, may Allah SWT accept good deeds, give His pleasure to us, give a reward worthy of all his 
efforts, and hopefully all of us in His protection. Gosh. The author is fully aware that this journal is far from perfection. Therefore, both suggestions and criticisms from readers are very authors expect for further improvement. Finally, the authors express gratitude to Allah SWT very deeply, and hopefully, this journal is useful for writers in particular and to all parties in general. 


\section{References}

[1] Antonovsky, A. Health, Coping, and Stress. 1st Ed. California: Jossey Bass Inc, 1979.

[2] Donohew, L., Lorch, E. P., \& Palmgreen, P. (1998). Applications of a theoretic model of information exposure to health interventions. Human Communication Research, 24, 454-468.

[3] E De Leeuw, and A Hussein. "Islamic Health Promotion and Interculturalization." Health Promotion International 14, no. 4 (1999): 347-53.

[4] Elson Haas M. "Nutritional Programs: Nutritional Program for Fasting." Accessed on August 17 2019. http://www.healthy.net/Health/Article/Nutritional Program for Fasting/

[5] Green, Lawrence W, and W M Kreuter. Health Promotion Planning: An Educational and Ecological Approach. 3rd ed. Mountain View: May field Publishing Company, 1999.

[6] Hussein, A A. "The Art of Health Promotion in Islam and The Contemporary Public Health Challenges." MPH Thesis, University of Maastricht, 1998.

[7] James E. Maddux and Melinda A. Stanley (1986). Self-Efficacy Theory in Contemporary Psychology: An Overview. Journal of Social and Clinical Psychology: Vol. 4, Special Issue: Self-Efficacy Theory in Contemporary Psychology, pp. 249-255.

[8] Kemm, J, and A Close. Health Promotion: Theory and Practice. London: Macmillan Press LTD, 1995.

[9] Kreps, G. L. (2003). The impact of communication on cancer risk, incidence, morbidity, mortality, and quality of life. Health Communication, 15(2), 161-169.

[10] Kreps, G. L. (2005). Disseminating relevant information to underserved audiences: implications from the Digital Divide Pilot Projects. Journal of the Medical Library Association, 93(4), 65-70.

[11] Kreps, G. L. (2012a). Strategic use of communication to market cancer prevention and control to vulnerable populations. [Special issue] Comunicação e Sociedade, 11-22.

[12] Kreps, G. L. (2012b). Strategic communication for cancer prevention and control: reaching and influencing vulnerable audiences. In A. Georgakilas (Ed.), Cancer prevention (pp. 375-388). Vienna: Intech.

[13] Kreps, G. L. (2013). Evaluating health communication interventions. In D. K. Kim, A. Singhal, \& G. L. Kreps (Eds.), Health communication: Strategies for developing global health pro- grams (pp. 352-367). New York: Peter Lang.

[14] Kreps, G. L., \& Sivaram, R. (2008). The central role of strategic health communication in enhancing breast cancer outcomes across the continuum of care in limited-resource coun- tries. Cancer, 113(S8), 2331-2337.

[15] Kreps, G. L., \& Sparks, L. (2008). Meeting the health literacy needs of vulnerable populations. Patient Education and Counseling, 71(3), 328-332.

[16] Leon Chaitow. "Fasting: Fasting for Health and as an Anti-Aging Strategy." Di akses pada 8 Desember 2015. http://www.healthy.net/Health/Article/Fasting for Health and as an Anti Aging Strategy/496

[17] Levin, Jeffrey S. "How Religion Influences Morbidity and Health: Reflections on Natural History, Salutogenesis and Host Resistance." Social Science \& Medicine, XIVth International Conference on the Social Sciences and Medicine, 43, no. 5 (September 1996): 849-64. doi:10.1016/0277-9536(96)00150-5.

[18] Levin, Jeffrey S., and Harold Y. Vanderpool. "Is Frequent Religious Attendance Really Conducive to Better Health?: Toward an Epidemiology of Religion." Social Science \& Medicine 24, no. 7 (1987): 589-600. doi:10.1016/0277-9536(87)90063-3.

[19] Maibach, E. W., \& Parrott, R. (Eds.). (1995). Designing health messages: Approaches from communication theory and public health practice. Thousand Oaks, CA: Sage.

[20] Maulana, A.O. "Islam and Health Dimension in 20th Century."University of Maastricht, 2002.

[21] Minkler, M. (2000). Using participatory action research to build healthy communities. Public Health Reports, 115(2-3), 91-197. 
[22] Minkler, M., \& Wallerstein, N. (Eds.). (2008). Community based participatory research for health: Process to outcomes (2nd ed.). San Francisco: Jossey -Bass.

[23] Naidoo, J, and J Wills. Health Promotion Foundations for Practice. 2nd ed. Bailliere Tindal: Harcourt Publishers Limited, 2000.

[24] National Research Council. (2000). Promoting health: Intervention strategies from social and behavioral research. Washington, DC: The National Academies Press.

[25] National Work Group on Literacy and Health. (1998). Communicating with patients who have limited literacy skills: report of the National Work Group on Literacy and Health. Journal of Family Practice, 46, 168-176.

[26] Neuhauser, L. (2001). Participatory design for better interactive health communication: a statewide model in the U.S.A. Electronic Journal of Communication/La Revue Electronique de Communication, 11(3-4). Retrieved from http://www.cios.org/EJCPUBLIC/011/3/ 01134.HTML

[27] Neuhauser, L., Constantine, W. L., Constantine, N. A., Sokal-Gutierrez, K., Obarski, S. K., Clayton, L., et al. (2007). Promoting prenatal and early childhood health: evaluation of a statewide materials-based intervention for parents. American Journal of Public Health, 97(10), 813-819.

[28] Neuhauser, L., Ivey, S. L., Huang, D., Engelman, A., Tseng, W., Dahrouge, D., et al. (2013). Avail- ability and readability of emergency preparedness materials for deaf and hard of hearing and older adult populations: issues and assessments. PLoS One, 8(2), e55614. http://dx.doi. org/10.1371/journal.pone.0055614.

[29] Neuhauser, L., \& Kreps, G. L. (2003). Rethinking communication in the e-health era. Journal of Health Psychology, 8(1), 7-22.

[30] Neuhauser, L., \& Kreps, G. (2008). Online cancer communication interventions: meeting the literacy, linguistic, and cultural needs of diverse audiences. Patient Education and Coun- seling, 71(3), 365-377.

[31] Neuhauser, L., \& Kreps, G. (2010). eHealth communication and behavior change: promise and performance. Journal of Social Semiotics, 20(1), 9-27.

[32] Neuhauser, L., Kreps, G. L., Morrison, K., Athanasoulis, M., Kirienko, N., \& Van Brunt, D. (2013). Using design science and artificial intelligence to improve health communication: Chronology MD case example. Patient Education and Counseling, 92(2), 211-217. http:// dx.doi.org/10.1016/j.pec.2013.04.006.

[33] Neuhauser, L., Kreps, G. L., \& Syme, S. L. (2013). Community participatory design of health communication programs: methods and case examples from Australia, China, Switzerland and the United States. In D. K. Kim, A. Singhal, \& G. L. Kreps (Eds.), Global health communication strategies in the 21st century: Design, implementation and evaluation. New York: Peter Lang.

[34] Neuhauser, L., \& Paul, K. (2011). Readability, comprehension and usability. In B. Fischhoff,

[35] N. T. Brewert, \& J. S. Downs (Eds.), Communicating risks and benefits: An evidence-based user's guide. Silver Spring, MD: U.S. Department of Health and Human Services.

[36] Neuhauser, L., Rothschild, B., Graham, C., Ivey, S., \& Konishi, S. (2009). Particip atory design of mass health communication in three languages for seniors and people with disabilities on Medicaid. American Journal of Public Health, 99, 2188-2195.

[37] Neuhauser, L., Rothschild, R., \& Rodriquez, F. M. (2007). MyPyramid.gov: assessment of liter- acy, cultural and linguistic factors in the USDA food pyramid website. Journal of Nutrition Education and Behavior, 39(4), 219-225

[38] Nicola Ruck. "Child Health and Islam." Supercourse: Epidemiology, the Internet, and Global Health. Accessed on August 07, 2019. http://www.pitt.edu/ super1/lecture/lec4981/index.htm.s

[39] Nutbeam, D, and E Harris. Theory in a Nutshell: A Practitioner's Guide to Commonly Used Theories and Models in Health Promotion. Sidney: University of Sydney, Department of Public Health and Community Medicine, National Centre for Health Promotion, 1998.

[40] Maulana, H. D. (2009). Health Promotion. Jakarta: EGC Medical Book Publisher. 
[41] Monica Eriksson, Bengt Lindstro"m (2006), Antonovsky's sense of coherence scale and the relation with health: a systematic review, J Epidemiol Community Health.

[42] Mittelmark, M. B., Sagy, S., Eriksson, M., Bauer, G. F., Pelikan, J. M., Lindström, B., \& Espnes, G. A. (2017). The handbook of salutogenesis. Springer.

[43] WHO . (2005).6th Global Conference on Health Promotion, Bangkok, Thailand, August 2005, and does not necessarily represent thedecisions or the stated policy of the World Health Organization. retrived from http://www.who.int/healthpromotion/conferences/6gchp/hpr 050829\%20BCHP.pdf.

[44] WHO. (Accessesd on August 2019). Global Health Promotion Confrences . Retrived From http://www.who.int/healthpromotion/conferences/en/

[45] WHO. (Accessesd on August 2019). Retrived from: http://www.who.int/healthpromotion/conferences/previous/ottawa/en/ 